\section{IMAGE UNAVAILABLE FOR COPYRIGHT REASONS}

\section{Romanian scientist elected president}

London. Romania made history last week by electing a 57-year-old research scientist and chancellor of the University of Bucharest as the first non-Communist president since the revolution of 1989. Emil Constantinescu, a mineralogist, defeated incumbent president Ion Iliescu by a comfortable margin of $\mathbf{1 0}$ per cent to secure an overall majority in parliament for his Conventia Democrata party.

Romania's 1989 revolution had left a Communist élite in power. Iliescu was a one-time heir-apparent to the dictator Nicolae Ceausescu, and his regime increasingly became the focus of public unrest.

From relative obscurity as a university chancellor, Constantinescu's public profile began to rise when he joined student protests against the Iliescu regime's alleged disregard of academic freedom. Earlier, mobs had stormed the university buildings and destroyed most of Constantinescu's collection of microscope mineral slides.

Opinion polls suggest that in the presidential elections he attracted a large proportion of the under-35 voters, who were attracted by his clean and untainted image. "There are no dark corners in my life, so I cannot be blackmailed," was one of his campaign slogans.

Before entering politics, Constantinescu - whose first degree is in law - was a prolific scientist and published mineralogy papers in Romanian, French and English journals. He concentrated on research under the Ceausescu regime, as a freeze on academic promotions ruled out a move into university management. He was appointed vice-chancellor soon after Ceausescu's fall, and took over as chancellor in 1992 (see Nature 372, 606; 1994).

Constantinescu has a tough job ahead of him. Half a century of Communism has crippled Romania's economy, once prosperous on the back of oil, gas and mineral wealth. He is also unfortunate in that most of his competitive neighbouring new Eastern European democracies have a head start in their transition to a freemarket economy.

Constantin Roman

\title{
Aeronomics institute leads protests against closures
}

Munich. Scientists at the Max Planck Institute for Aeronomics in Lindau, Germany, took to the streets earlier this month as part of a vigorous campaign to save their institute from closure. But the campaign, which includes soliciting support from scientific colleagues around the world, appears so far to have made little impact.

Last week the senate of the Max Planck Society endorsed the proposal of its president, Hubert Markl, that staff numbers be reduced by 512 in west Germany before the end of the decade by closing four institutes, including the Lindau institute, and at least ten departments (see Nature 383, 566; 1996).

The harsh measures have been prompted by an across-the-board cut in public-sector jobs imposed by the federal government, combined with a political decision within the society to develop its institutes in east Germany to western levels.

All four institutes earmarked for closure have launched protests, but none has been more forceful than that of the aeronomics institute. It has set up an Internet home page and has sent more than 700 letters to colleagues asking for support. More than 130 have already responded by writing to Markl asking for a reprieve, or at least for protection of the institute's current commitments to planetary science.

A demonstration held jointly with the Max Planck Institute for History - also under threat of closure - in neighbouring Göttingen attracted more than 500 people.

Young scientists at the aeronomics institute have been actively involved in the campaign to keep it open. One reason is that their future careers depend on Germany not pulling out of planetary science, according to Norbert Krupp, a 33-year old physicist who is helping to develop a microdetector for an instrument aboard Cassini, the US-European mission to Saturn due for launch next year.

There is no other large institute in Germany specializing in planetary science, and the 30 or so young scientists at Lindau have already become too specialized to change track easily, Krupp says.

Markl has repeatedly promised that commitments to international projects such as the European Space Agency's cometary mission Rosetta and Cassini will be fulfilled. He hopes that the projects can be transferred to DLR, Germany's national research centre for space research.

If DLR chooses not cooperate - which seems likely, given the pressure on its own budget - the Max Planck Society will find a way to support the projects itself, insists Markl. But, asks Krupp, who will be around to analyse the data from instruments developed in Germany, if German planetary science is allowed to die before the missions reach their target planets?

Markl says he plans to continue to consult widely before his final proposal goes through its formal first reading at the next MPS senate meeting in March. He says that he hopes a final decision will be reached within the following few months, so as not to stretch out the "cruel waiting time" for the scientists involved.

Alison Abbott

\section{Dual role for Australian research chief}

Sydney. The Australian government has appointed John Stocker as both its chief scientist and the chairman of the Australian Science, Technology and Engineering Council (ASTEC).

Stocker was director of research for the pharmaceutical company Hoffman-La Roche in Basel, Switzerland, before returning to Australia to serve as chief executive of the Commonwealth Scientific and Industrial Research Organisation from 1990 to 1995.

His appointment has been widely welcomed, but there is less enthusiasm about the role he has been asked to fill. Stocker will be responsible in both posts to the minister for science and technology, Peter McGauran, who is not a member of the cabinet. Under the former Labor government, both his predecessors reported to the prime minister, although Stocker says he retains an "advisory line" to the premier.

Further concern that the status of the chief scientist post is being downgraded centres on the fact that it will be only a part-time position. Stocker will spend one day a week in each post, while continuing as a company director, a consultant to technology-based industry and a professorial fellow in the University of Melbourne.

Joe Baker, president of the Federation of Australian Scientific and Technological Societies, argues that the chief scientist's position is "too big to be handled in one day a week". Labor's science spokesman, Martyn Evans, says the changes "confirm that the government has downgraded science".

But Stocker maintains that his experience and his close connections with industry will benefit the government's stated intention of improving links between science and the economy. And McGauran rejects claims that the role is diminished by Stocker working one-fifth of the combined time of his predecessors. 